\title{
Emotional Anguish at Work: The Mediating Role of Perceived Rejection on Workgroup Mistreatment and Affective Outcomes
}

\author{
Nikki L. Penhaligon and \\ Winnifred R. Louis \\ The University of Queensland
}

\author{
Simon Lloyd D. Restubog \\ The University of New South Wales
}

\begin{abstract}
In this study, the authors pay particular attention to mistreatment directed toward an organizational member from fellow workgroup members. The study contributes to the growing body of literature that examines the mistreatment of employees in the workplace. The authors propose that mistreatment by the workgroup would contribute to feelings of rejection, over and above mistreatment by the supervisor. In addition, the authors tested the mediating role of perceived rejection between workgroup mistreatment and affective outcomes such as depression and organization-based self-esteem. Part-time working participants $(N=142)$ took part in the study, which required them to complete a questionnaire on workplace behaviors. Results indicated that workgroup mistreatment contributed additional variance to perceived rejection over and above supervisory mistreatment when predicting depression and organization-based self-esteem. The results also indicated that perceived rejection mediates the relationship between mistreatment and affective outcomes. Results are discussed and implications for research and practice are considered.
\end{abstract}

Keywords: depression, organization-based self-esteem, rejection, workgroup mistreatment

In the past decade, the study of harmful workplace behaviors has attracted a great deal of attention in the organizational and management sciences (Britt, Dickson, Moore, Castro, \& Alder, 2007; Weiss \& Cropanzano, 1996). Within this theme, researchers have examined a variety of behaviors. For example, supervisors engage in hostile verbal and nonverbal actions toward their subordinates (Tepper, 2000). They bully employees by treating them as incompetent and blaming them for their own errors (Lee \& Brotheridge, 2006). Organizational members are even reported to engage in long-term behaviors with the intent to hinder the work success, interpersonal relationships, and reputation of other employees (Duffy, Ganster, \& Pagon, 2002). Not surprisingly, these behaviors can negatively affect both

Nikki L. Penhaligon and Winnifred R. Louis, School of Psychology, The University of Queensland, Brisbane, Australia; Simon Lloyd D. Restubog, The Australian School of Business, The University of New South Wales, Sydney, Australia.

A version of this article was presented at the $21^{\text {st }}$ annual meeting of the Australian-New Zealand Academy of Management in Sydney, Australia. We would like to note that the various contributions of the three authors are of equal value to the overall preparation of this article. Special thanks to Nerina Jimmieson, Alannah Rafferty, and Tom Zagenczyk for their insightful comments on a draft of this article.

Correspondence concerning this article should be addressed to Nikki Penhaligon, School of Psychology, The University of Queensland, St. Lucia, Brisbane, 4072, QLD, Australia. E-mail: n.penhaligon@psy.uq.edu.au employees and the organization as a whole (Ashforth, 1997; Keashly, Trott, \& MacLean, 1994). For the purpose of this article, we used the term workplace mistreatment to encompass a variety of harmful workplace behaviors from bullying (Lee \& Brotheridge, 2006) and mobbing (Leymann, 1996) to social undermining (Duffy et al., 2002) and abusive supervision (Tepper, 2000).

Although research has demonstrated that these forms of mistreatment create harm, there has been little investigation as to why this occurs. The common mechanisms linking mistreatment and negative outcomes have yet to be identified (Harvey \& Keashly, 2003). Recently, there has been a call to develop a deeper understanding of the underlying mechanisms involved in harmful workplace behavior (e.g., Griffin \& Lopez, 2005). A key argument of the present study was that one common factor that underlies the negative effects of workplace mistreatment is the perception that this behavior is rejecting. The concept of rejection has been predominantly examined in the social psychological literature (e.g., Baumeister, Dewall, Ciarocco, \& Twenge, 2005; Leary, Springer, Negel, Ansell, \& Evans, 1998), with little research investigating its negative consequences in the workplace. Recently, some researchers have begun to acknowledge the important role of rejection in the workplace (e.g., Schneider, Hitlan, \& Radhakrishnan, 2000). However, there is still limited theorizing about how rejection takes place in this setting. For example, focusing solely on the overt 
behaviors of mistreatment can be misleading because a range of distinct processes may underpin these behaviors. Some behaviors that appear harmful may actually have constructive mechanisms driving them (e.g., prosocial rule breaking; Neuman \& Baron, 2005). Examining the underlying psychological mechanisms mediating mistreatment and outcomes therefore addresses a major gap in the literature and contributes to our understanding of why mistreatment is so harmful. An understanding of rejection as an underlying mechanism is also important to aid in the development of interventions to help minimize the adverse impact of mistreatment on employees. In this study, we tested the hypothesis that it is not only the behavior itself but also the underlying psychological message such mistreating behavior sends that creates harm to the target.

\section{Theoretical Background}

The mistreatment of employees in the workplace continues to receive increased attention in the literature (e.g., Baron \& Neuman, 1996; Duffy et al., 2002; Tepper, 2000). The research in this area refers to the mistreatment of employees with a number of different labels (e.g., social undermining, bullying, mobbing, aggressive communication, abuse, etc.), but researchers tend to agree that there are similarities between the constructs and that they often result in similar negative outcomes (Bowling \& Beehr, 2006; Lapierre, Spector, \& Leck, 2005; Sheppard, Lewicki, $\&$ Minot, 1992). Behaviors of this nature can negatively affect organizational effectiveness and productivity (Hirigoyen, 1998), employee satisfaction (Infante \& Gorden, 1985), and motivation (Myers \& Rocca, 2001) and increase employee turnover, absenteeism, (Kennedy, Homant, \& Homant, 2004; Lee \& Brotheridge, 2006) and stress levels, resulting in greater compensation claims against the organization (Bassman, 1992). In addition, people who experience mistreatment often report higher levels of negative emotions, including bitterness, anger, and resentment (Stecher \& Rosse, 2005), and even severe psychological problems such as depression (Pagal, Erdly, \& Becker, 1987; Spector \& Jex, 1998) and damaged self-esteem (Ashforth, 1997; Spector \& Jex, 1998).

\section{The Role of the Workgroup}

To date, research investigating mistreatment in the workplace has tended to focus on the overall behaviors directed by the supervisor toward the employee as a key driver of employees' affective reactions.
However, recently, researchers have recently begun to recognize that harm can also result when mistreatment is directed by other sources, including other workgroup members (e.g., Duffy et al., 2002; Schat, Frone, \& Kelloway, 2006). These studies note the importance of one's relationship with his or her workgroup. Duffy and colleagues (2002) demonstrated that both social undermining by the supervisor and social undermining by coworkers resulted in increased levels of somatic complaints and active counterproductive behaviors. However, they found no significant effects of social undermining by the supervisor or workgroup on affective outcomes. Conversely, the interpersonal conflict literature has demonstrated that both supervisor and workgroup negativity can influence affective outcomes. For example, Frone (2000) showed that interpersonal conflict from the supervisor and interpersonal conflict from the workgroup have significant effects on employee well-being. He showed that coworker interpersonal conflict affects personal outcomes such as increased depression and lower self-esteem, even when supervisor conflict is controlled. Recently, Bruk-Lee and Spector (2006) also demonstrated that workgroup conflict plays a significant role over and above conflict with the supervisor in generating significant negative emotional reactions in the recipient.

In this study, we were interested in further examining the unique contribution and outcomes of workgroup mistreatment. Specifically, we focused on the impact of workgroup mistreatment on two affective outcomes: depression and organization-based selfesteem. Depression is often characterized by feelings of sadness, loss of interest, low energy, and poor concentration (Santor \& Coyne, 1997). Research suggests that it is a common psychological disorder among working populations and can have destructive consequences on work performance (e.g., Kessler et al., 2006) and interpersonal relationships (e.g., Faust, Baum, \& Forehand, 1985). Organization-based selfesteem refers to the way an individual evaluates his or her worthiness as an organizational member (Gardner \& Pierce, 1998). A considerable number of studies have demonstrated that self-esteem can suffer under disapproval from others (Leary \& Downs, 1995) and that low self-esteem is associated with poor work outcomes (Brockner, 1988; Hollenbeck \& Brief, 1987). Based on these empirical and theoretical considerations, we anticipated that workgroup mistreatment would likely affect these affective outcomes. We therefore predicted that: 
Hypothesis 1a: Workgroup mistreatment will be positively associated with depression over and above the effects of supervisory mistreatment.

Hypothesis 1b: Workgroup mistreatment will be negatively associated with organization-based self-esteem over and above the effects of supervisory mistreatment.

\section{Rejection}

Within the social psychological literature, rejection is defined as a form of being excluded from or devalued by a desired person, group, or relationship (MacDonald \& Leary, 2005). Research investigating perceived rejection has consistently demonstrated its association with negative affective outcomes, including depression (Coie, Terry, Zakriski, \& Lochman, 1995), feelings of unworthiness (Craighead, Kimball, \& Rehak, 1979), loneliness (Jones, 1990), and decreased self-concept (Buhs, 2005) and self-esteem (Baumeister \& Leary, 1995). Similarly, rejection has been investigated as a behavioral response to a wrongdoing. For example, whistleblowers are given the silent treatment to punish them for speaking out (Miceli \& Near, 1984). However, to date, little attention has been paid to the organizational and individual consequences that can result from perceived rejection in the workplace. Recently, Hitlan, Kelly, Schepman, Schneider, and Zarate (2006) demonstrated that participants rejected by their workgroup were less likely to want to remain at the organization, were less emotionally attached than accepted participants, had lower overall organizational commitment, and were less likely to engage in organizational citizenship behaviors. Further still, Hitlan, Cliffton, and DeSoto (2006) demonstrated that men who perceived themselves to be rejected at work were dissatisfied with their supervisor and coworkers. Altogether, these studies demonstrate the important role rejection plays in shaping employee functioning in the workplace, and also that there is a continuing need to examine the impact of rejection within this organizational context.

In this study, we argue that perceived rejection acts as an underlying psychological mechanism linking workgroup mistreatment and affective outcomes. This line of reasoning is guided by two theoretical perspectives. First, belongingness theory (Baumeister \& Leary, 1995) suggests that humans are motivated by a basic need to feel as though they belong. We go to extreme lengths to associate with, be liked by, and belong to groups. It also suggests that it is not only interactions with others that are important, but also that these interactions must be positive, pleasant, and without conflict and negative affect (Leary \& Baumeister, 2000). Violations to this need to belong also result in the experience of depression (Coie et al., 1995) and damaged self-esteem (Leary \& Baumeister, 2000). Second, social identity theory (Tajfel \& Turner, 1979) states that individuals define themselves on the basis of groups to which they belong, and that these groups provide them with a sense of stability and security. Categorizing oneself as a group member gives individuals a distinct meaning, creating a positively valued social identity (Hogg $\&$ Terry, 2000). It also suggests that group acceptance is an important determinant of well-being. Guided by the principles of social identity theory (Tajfel \& Turner, 1979) and belongingness theory (Baumeister \& Leary, 1995), and based on the theoretical perspective that rejection involves being excluded from or devalued by a desired person, group, or relationship (MacDonald \& Leary, 2005), we argue that employees who experience mistreatment from their workgroup may not feel that they have a positive relationship with or are valued by the source of the mistreatment. Whether it be with a supervisor or a fellow workgroup member, a positive relationship is often desired. An employee who experiences mistreatment may not feel valued by the source of the mistreatment, feeling he or she no longer belongs, and leading to the perception of such behavior as rejecting. In turn, we suggest that this will induce feelings of depression and a lack of self-worth as an organizational member.

Hypothesis 2a: Perceived rejection will mediate the relationship between workgroup mistreatment and depression.

Hypothesis 2b: Perceived rejection will mediate the relationship between workgroup mistreatment and organization-based self-esteem.

\section{Method}

\section{Participants}

Part-time working participants $(N=142)$ recruited from a large Australian university took part in the study. To be eligible to participate, participants must have been currently employed in a part-time or fulltime capacity. Participants received either compensation $(n=79)$ or course credit $(n=63)$ for their participation. The 96 women and 44 men (2 unspec- 
ified) ranged in age from 17 to 47 years, with a mean age of 19.90 years $(S D=4.49)$. Participants worked an average of 17.51 hours per week $(S D=9.29)$ and had an average of 20.50 months of experience $(S D=$ 17.37) in their organization of reference. Participants' roles included hospitality (e.g., waitress, bartender), administration (e.g., office worker, manager, receptionist), and sales (e.g., customer service). Twenty-three participants did not specify their work role.

\section{Procedure}

Participants were recruited from a large Australian university, receiving either course credit or monetary compensation for their participation. Prior to the administration of the questionnaire, participants were provided with an introductory sheet informing them of study requirements. Questionnaires were administered and counterbalanced either to present measures of workgroup mistreatment followed by supervisory mistreatment or the reverse. Participants were required to read the questionnaire and answer the questions. Participants were assured that their participation in the study was voluntary, they were free to withdraw from the study at any time without penalty, and that their results were confidential. At the completion of the survey, participants were thanked and debriefed by the first author.

\section{Measures}

Workgroup mistreatment. Previous research and pre-established scales were combined to create a 35 item measure of workplace mistreatment by the workgroup (Duffy et al., 2002; Einaresen, 2000; Leymann, 1996; Tepper, 2000). The scale began with the instructions, "Think about your relationship with other colleagues in your immediate work environment. These colleagues may be members of a team you work in, or employees of a similar status in your organization. Please indicate how often you have experienced the following behaviors directed toward you from a colleague in the workplace." The full scale is reported in the Appendix. Participants reported how often in the past 12 months they experienced the listed behaviors on a 7-point scale ranging from not at all (1) to very often (7). This scale yielded a reliability coefficient of $\alpha=.85$.

Depression. Ten items were used to assess depressive symptoms. These items were adapted from Santor and Coyne's (1997) depression as a symptom of distress scale (e.g., "To what extent did you have trouble keeping your mind on things?"). Participants were required to rate how often in the past 12 months they had experienced such depressive symptoms on a 7-point scale ranging from not at all (1) to very often (7). This scale yielded a reliability coefficient of $\alpha=.80$.

Organization-based self-esteem. Seven items (derived from Pierce, Gardner, Cummings, \& Dunham, 1989) were used to assess organization-based self-esteem (e.g., "To what extent do you feel you count around others at work?"). Participants were asked to report how often they experienced the feelings described by Pierce and colleagues (1989) on a 7-point scale ranging from not at all (1) to very often (7). This scale yielded a reliability coefficient of $\alpha=.87$.

Perceived rejection. Four items were used to assess perceived rejection as a global measure. We used a global assessment of perceived rejection as previous research has suggested that global measures can better capture the subjective experiences of employees and be more effective in reducing socially desirable responses (e.g., Crossley, Bennett, Jex, \& Burnfield, 2007; Ironson, Smith, Brannick, Gibson, \& Paul, 1989). These items were derived from MacDonald and Leary's (2005) definition (e.g., "I felt excluded," "I felt ostracized," "I felt disliked," and "I felt rejected"). Participants were asked to report how often they experienced these feelings on a 7-point scale ranging from not at all (1) to very often (7). This scale yielded a reliability coefficient of $\alpha=.85$.

Control variables. We controlled for two variables in our analyses to eliminate alternative explanations. First, we controlled for supervisor mistreatment. The supervisory mistreatment scale began with the instructions, "Think about your relationship with your immediate supervisor or boss at work. Please indicate how often you have experienced the following behaviors directed toward you from this supervisor in the workplace." The items repeated the same scale used to measure workgroup mistreatment, with the word colleagues replaced by the word boss (e.g., "My boss tells me my thoughts or feelings are stupid"). Again, participants reported how often in the past 12 months they experienced the listed behaviors on a 7-point scale ranging from not at all (1) to very often (7). A principal components analysis using a varimax rotation distinguished the items concerning supervisor mistreatment from the items concerning workgroup mistreatment, with no items that crossload on both dimensions. The supervisory mistreatment measure yielded a reliability coefficient of $\alpha=$ 
.87. Second, as self-report data can be subject to demand characteristics (Gardner \& Martinko, 1998), eight items were used to control for the social desirability of the participants' responses. These items were derived from the Marlow-Crowne Social Desirability Scale (e.g., "Are you always willing to admit when you make a mistake?"). Participants were required to answer either "Yes" or "No" to a number of such items. Four items were reverse scored (e.g., "Have there been occasions when you have taken advantage of someone?"). The eight-item measure of social desirability yielded a reliability coefficient of $\alpha=.67$.

\section{Results}

\section{Preliminary Analyses}

Table 1 represents the means, standard deviations, and intercorrelations among the independent variables, dependent variables, and the mediator. All correlations supported the predicted directions. More specifically, workgroup mistreatment was significantly positively correlated with depression and perceived rejection. Furthermore, workgroup mistreatment was significantly negatively correlated with organization-based self-esteem. The table also indicates a low correlation between supervisory and workgroup mistreatment, suggesting that they tap into different constructs.

\section{Preliminary Diagnostics}

Prior to the testing of the mediation relationship, inspection of the data revealed no evidence of violations of the assumptions of hierarchical multiple regression. An assessment of the intercorrelations among the independent variables suggested that they were low to moderate and multicollinearity was not a threat (Tabachnick \& Fidell, 2001). Further analyses revealed no evidence of multivariate outliers or suppressor variables.

\section{Test of Hypotheses}

We hypothesized that workgroup mistreatment would be positively associated with depression and negatively associated with self-esteem, when controlling for supervisory mistreatment. We further hypothesized that these relationships would be mediated by perceived rejection. Baron and Kenny's (1986) test of mediation was used to examine these relationships.

For mediation to occur, three conditions must be satisfied (Baron \& Kenny, 1986). First, the independent variable (workgroup mistreatment) must be related to the dependent variables (depression and organization-based self-esteem). The data in Table 2 suggest that workgroup mistreatment was positively related to depression $(\beta=.35, p<.01)$, over and above the effects of supervisory mistreatment $(\beta=$ $.38, p<.01)$ and social desirability $(\beta=-.05, n s)$. In addition, workgroup mistreatment was negatively related to organization-based self-esteem $(\beta=-.20$, $p<.05$ ), over and above the effects of supervisory mistreatment $(\beta=-.17, p<.05)$ and social desirability $(\beta=.04, n s)$. This supports Hypotheses 1a and $1 \mathrm{~b}$ and satisfies the first condition of mediation.

Second, the independent variable must be related to the proposed mediator (perceived rejection). An examination of the beta weights revealed that workgroup mistreatment was positively related to perceived rejection $(\beta=.39, p<.01)$, over and above the effects of supervisory mistreatment $(\beta=.34, p<$ $.01)$ and social desirability $(\beta=.05, n s)$. This provided support for the second condition of mediation. Third, to establish mediation, the effect of the inde-

Table 1

Means, Standard Deviations, and Intercorrelations Among the Study Variables

\begin{tabular}{lcrrrrrrr}
\hline \multicolumn{1}{c}{ Variable } & $M$ & \multicolumn{1}{c}{$S D$} & 1 & 2 & 3 & 4 & 5 & 6 \\
\hline 1. Social desirability & 2.14 & .55 & .67 & & & & & \\
2. Supervisory mistreatment & 1.77 & .81 & -.10 & $(.87)$ & & & \\
3. Workgroup mistreatment & 1.70 & .67 & -.11 & $.35^{* * *}$ & $(.85)$ & & \\
4. Rejection & 1.83 & 1.11 & .01 & $.48^{* *}$ & $.51^{* *}$ & $(.85)$ & \\
5. Depression & 2.06 & .85 & -.09 & $.51^{* *}$ & $.49^{* *}$ & $.79^{* *}$ & $(.80)$ & \\
6. Organizational-based self-esteem & 5.22 & 1.19 & .07 & $-.24^{* *}$ & $-.27^{* *}$ & $-.58^{* *}$ & $-.52^{* * *}$ & $(.87)$ \\
\hline
\end{tabular}

Note. The reliability coefficients appear in the parentheses along the main diagonal.

${ }^{*} p<.05 .{ }^{* *} p<.01$. 
Table 2

Hierarchical Regression Results Examining the Mediating Role of Perceived Rejection

\begin{tabular}{|c|c|c|c|c|c|c|c|c|c|c|}
\hline \multirow[b]{2}{*}{ Variable and step } & \multicolumn{5}{|c|}{ Depression $\beta$} & \multicolumn{5}{|c|}{ Organizational-based self-esteem $\beta$} \\
\hline & Step 1 & Step 2 & Step 3 & $R^{2}$ & $\Delta R^{2}$ & Step 1 & Step 2 & Step 3 & $R^{2}$ & $\Delta R^{2}$ \\
\hline \multicolumn{11}{|l|}{ Step 1: Controls } \\
\hline Social desirability & -.09 & -.05 & -.09 & & .06 & .04 & .07 & & & \\
\hline Supervisor mistreatment & $.51^{* * *}$ & $.38^{* *}$ & $.16^{* *}$ & $.27^{* *}$ & $-.24^{*}$ & $-.17^{*}$ & .04 & .06 & & \\
\hline \multicolumn{11}{|l|}{$\begin{array}{l}\text { Step 2: Main effect of } \\
\text { independent variable }\end{array}$} \\
\hline Workgroup mistreatment & & $.35^{* *}$ & .09 & $.37^{* * *}$ & $.11^{* * *}$ & & $-.20^{*}$ & .04 & $.10^{*}$ & $.04^{*}$ \\
\hline \multicolumn{11}{|l|}{ Step 3: Inclusion of mediator } \\
\hline Perceived rejection & & & $.67^{* * *}$ & $.66^{* *}$ & $.29^{* * *}$ & & & $-.62^{* *}$ & $.34^{* *}$ & $.24^{* *}$ \\
\hline
\end{tabular}

pendent variable on the dependent variables must substantially decrease on inclusion of the mediator. When perceived rejection was added into the equation, the beta coefficient of the relationship between workgroup mistreatment and the affective outcomes decreased from $.35, p<.01$, in the second step to $\beta=.09, n s$, in the third step for depression, and from $-.20, p<.01$, to $\beta=.04, n s$, for organization-based self-esteem. This supports the third condition for mediation.

Finally, the Sobel test (Sobel, 1982) was used to formally evaluate whether the direct path between the independent variable and the outcome variables through the mediator was significant. Results revealed that perceived rejection mediated the positive relationship between workgroup mistreatment and depression $(z=4.91, p<.01)$ and also the negative relationship between workgroup mistreatment and organization-based self-esteem $(z=-4.31, p<.01)$. The effect proportion mediated $\left(P_{M}\right.$; Shrout \& Bolger, 2002) was also calculated and was large for both depression $\left(P_{M}=0.74\right)$ and organization-based self-esteem $\left(P_{M}=1.00\right)$. These results support the full mediation by perceived rejection of the relationship between workgroup mistreatment and the outcome variables of depression and organization-based self-esteem and provide support for Hypotheses 2a and $2 \mathrm{~b} .^{1}$

\section{Discussion}

This study contributes to the growing body of literature that examines harmful behaviors at work (e.g., Duffy et al., 2002; Schat et al., 2006; Tepper, 2000). Notably, this study extends this research to investigate why this behavior is so damaging, suggesting that perceived rejection acts as an underlying psychological mechanism to create harm. The results support our hypotheses that workgroup mistreatment would be positively associated with depression and negatively associated with organization-based selfesteem, independent of supervisory mistreatment. Our results also demonstrate that perceived rejection fully mediates the relationship between workgroup mistreatment and depression and organizationalbased self-esteem.

\section{Theoretical Implications}

The finding that workgroup mistreatment contributes to the participants' experience of depression and lower self-esteem over and above supervisory mistreatment supports previous findings demonstrating the important role of the workgroup in influencing employee emotions at work (e.g., Frone, 2000). In this study, supervisor and workgroup mistreatment could be empirically distinguished and exerted independent effects. Although the dyadic relationship between a supervisor and an employee has consistently been demonstrated to significantly affect employee functioning (e.g., Ashforth, 1997; Duffy et al., 2002), serious affective outcomes can also result when an employee is mistreated by a fellow workgroup member, as demonstrated by the present study (see also Bruk-Lee \& Spector, 2006; Frone, 2000).

\footnotetext{
${ }^{1}$ It should be noted that the present results remain the same when workers who were less experienced in their workplace are excluded (i.e., working fewer than $10 \mathrm{hr}$ per week and having been employed at their organization of reference for less than 6 months) in the analysis. To maintain the diversity of our sample pool and capitalize on the statistical power, we included all 142 participants in the analysis.
} 
A partial inconsistency may be noted in that the present data do not appear to replicate the differential effects of supervisory and workgroup mistreatment, as found by Frone (2000), whereby workgroup conflict was more closely linked to affective outcomes than was supervisory conflict. Our results suggest that the effects of both types of mistreatment on affective outcomes appear to be comparable. Although further research is needed to clarify the context in which workgroup variables will dominate supervisor variables, it seems relevant to note that interpersonal conflict (Frone, 2000) is theoretically distinct from mistreatment as conceptualized in this study. Victimization of the target is not required in interpersonal conflict (Bruk-Lee \& Spector, 2006). It may be that interpersonal conflict can occur without triggering rejection in some cases, such as when conflict is seen as a productive sign of commitment and engagement with a relationship. This may be an avenue for future research to address. In addition, developmental variables could be examined: It may be that the adolescent participants recruited by Frone (2000) were more sensitive to peer conflict than the older university part-time workers of the present study. In contrast, the part-time workers of the current study were recruited from a university context and, as such, their contacts with colleagues may be more fleeting and less emotionally important. Again, we encourage future research to examine these apparent differences.

The present research is one of the first (see also Hitlan et al., 2006) to introduce the study of perceived rejection in the workplace. We were able to expand this research to also investigate the crucial role rejection plays in employee emotional wellbeing. Furthermore, our study specifically aimed to provide an explanation for why workplace mistreatment can be harmful. It is the first to identify the role of perceived rejection as a mediating link between workplace mistreatment and affective outcomes. This is critical as a theoretical understanding of psychological mechanisms involved in mistreatment may have a number of practical applications. If we understand the reason for the harm, we can target programs accordingly. An understanding of the psychological underpinnings of mistreatment may be used to create practical interventions to minimize the harm of workplace mistreatment. For example, employee assistance programs could be targeted to provide organizational members with practical cognitive skills to better cope with mistreatment in the workplace. Thereby, even if the mistreatment continues, employees may have the ability to appropriately cope with the situation, without internalizing the mistreatment. More effective coping strategies (e.g., thought stopping and cognitive restructuring) may result in less harm to the individual, and consequently less reactivity and harm to the organization.

\section{Practical Implications}

The findings of the present study have important practical implications. Our results demonstrate that mistreatment can damage employees' self-esteem. We know that people with lower self-esteem tend to respond to events in their environment more strongly (Brockner, 1988). Therefore, we suggest that a chain of mediation may be occurring. It is possible that affective outcomes may serve as mediators linking rejection to certain negative outcomes. For example, we know that affective reactions can drive certain undesirable behaviors (e.g., absenteeism and even negative and counterproductive behaviors, such as spreading rumors) as a reaction to unfair treatment in the workplace (e.g., Restubog, Bordia, \& Tang, 2007). We suggest that the affective reactions of mistreatment may intensify certain behavioral reactions at work, resulting in significant costly implications for the organization at large. In an attempt to avoid such negative behavioral responses, we suggest that there is a strong need to make employees feel included within the workplace. This may be achieved by educating supervisors and organizational members regarding the damaging nature and associated consequences of mistreating behaviors. In addition, members could be encouraged to embrace interactional justice behaviors, such as treating each other with respect, dignity, kindness, and consideration (Donovan, Drasgow, \& Munson, 1998; Greenberg, 2006). These may contribute to increased feelings of inclusiveness in the workplace, thereby minimizing the adverse consequences of mistreatment and perceived rejection.

Finally, the results demonstrate the powerful role of the workgroup in influencing employee emotions, independent of the supervisor. An independent effect of workgroup mistreatment raises the possibility of an independent effect of workgroup support. We know from previous research that social support can buffer the effects of workplace mistreatment (e.g., Duffy et al., 2002; Hobman, Restubog, Bordia, \& Tang, in press). Therefore, if this independent effect of workgroup support is found, positive coworker treatment could be used to buffer the effects of supervisor mistreatment, rejection, and their consequences. Encouraging positive coworker interactions 
may be achieved through interactional justice training (e.g., Greenberg, 2006).

\section{Strengths, Limitations, and Future Directions}

Our study is not without limitations. Most notably, the nature of our sample may come under scrutiny. Participants consisted of part-time workers who worked an average of $17.51 \mathrm{hr}$ per week. As they were not full-time employees, the generalizability of the findings to the larger workforce may be questioned. Research has suggested that full-time workers and part-time workers differ in their attitudes toward work (e.g., Markey, Hodgkinson, \& Kowalczyk, 2002); therefore, parttime workers may not be as strongly committed to their work as full-time workers. As a result, we would expect to see stronger, more significant results when full-time workers are examined in future research given that time exposure to mistreatment and vulnerability to rejection may be stronger. Consistent with this notion, our results indicate even stronger findings when those participants who worked fewer hours per week and had shorter tenure were excluded from the analyses. However, as we did not systematically test this hypothesis or compare the results of part-time versus full-time workers, we must be careful in drawing strong conclusions from our data. To test this proposition and the generalizability and value of this model, future studies using a full-time working population is recommended.

Second, as we did not collect data over time, we cannot infer causal relationships from our findings. It may be that variables other than rejection mediate mistreatment to create harm, or that those individuals who are subject to depression and lower self-esteem interpret certain behaviors as more mistreating or rejecting than others. However, it has been argued that the mere perception that one has been rejected is just as important as the rejecting behavior itself (Leary, 2001), suggesting that the participants' mere perception of rejection is strong enough to result in harm. Cross-sectional research has also been criticized for common method variance, which can inflate correlations between variables (Spector, 2006). The use of experimental vignettes to manipulate the present variables should help to minimize this risk. Furthermore, the use of experimental vignettes in future studies may also help to minimize the risks involved with self-report methodology, which can be subject to demand characteristics (Gardner \& Martinko, 1998). However, importantly in the present study, the relationships of interest held even after controlling for social desirability, suggesting that our data were not affected by this bias.
It is important to consider the manner in which workgroup mistreatment was operationalized. It is possible that some participants may have interpreted colleagues as meaning any fellow colleague they work with and not specifically their workgroup members. However, participants were specifically directed to focus on their immediate work environment, such as members of their work team. Moreover, we suggest that when people are asked to think of their colleagues, they may be likely to think of those closest to them and therefore answer with their workgroup in mind (cf. Frone, 2000). We also suggest that future research employ more common methods of assessing the frequency of mistreatment, such as those used by Bennett and Robinson (2000; $1=$ never through $7=$ daily). In addition, future research may also look to assess differences among the measures combined in the present study into our 35-item mistreatment scales. It may be that some processes of mistreatment (e.g., bullying vs. mobbing) have different properties when engaged in by a supervisor versus by coworkers, and this possibility could be systematically addressed in future research.

Our study points to a number of other avenues for future research. We know that employees often react behaviorally as a result of mistreatment, for example, through employee deviance (Bordia, Restubog, \& Tang, in press) or workplace aggression (Douglas \& Martinko, 2001). In addition, there is evidence that individuals have a similar reaction to rejection. Rejected individuals have been reported to respond by working harder on tasks (Williams \& Sommer, 1997) or even engaging in aggressive behaviors (Twenge, Baumeister, Tice, \& Stucke, 2001). Furthermore, in extreme cases, rejection has been linked to physical violence. For example, Eric Harris and Dylan Kleebold, the two students responsible for the Columbine High School massacre, suffered from severe social rejection by their peers (Leary, Kowalski, Smith, \& Phillips, 2003). The results of the current study may help to identify why some employees become perpetrators of aggressive behaviors and others do not. We suggest that, when given the opportunity, mistreated and consequently rejected employees will respond behaviorally in either a negative or positive way (e.g., aggression or ingratiation). We encourage future research to examine these behavioral consequences.

Second, recent studies encourage researchers to examine the interaction between individual and situational predictors (cf. Aquino, Galperin, \& Bennett, 2004; Inness, Barling, \& Turner, 2005; Restubog, Bordia, \& Bordia, in press). Research on social learning theory (Bandura, 1977) and social information processing 
theory (Salancik \& Pfeffer, 1978) suggests that people often look to others to guide them in how to behave in certain situations and model this behavior (e.g., Robinson \& O'Leary-Kelly, 1998). When experiencing mistreatment, an employee may look to others to guide their response to the situation. As a result, we would expect organizational norms to moderate the relationships examined in the present study. Furthermore, an individual's response to mistreatment may be influenced by his or her personality traits. For example, hostile attribution bias, or the tendency of a person to interpret events in a hostile light (Dodge \& Coie, 1987), may influence how an individual responds to mistreatment. People high on this trait tend to interpret events in a hostile manner, and can consequently respond in a more negative manner for the same level of provocation (Douglas \& Martinko, 2001). We suggest that researchers test the possible moderating role of hostile attribution bias on the relationships examined in the present study.

Finally, we measured workplace mistreatment from two distinct sources, the supervisor and the workgroup. These measures lend themselves to the possibility of examining the interaction between supervisor and workgroup mistreatment. For example, what is the impact of having both a supervisor and coworkers mistreat an employee? In addition, it would be interesting to examine the possible moderating role of self-esteem. For example, high self-esteem may act to buffer the effects of workplace mistreatment and perceived rejection. We encourage future researchers to further investigate these relationships.

\section{Conclusion}

There is little doubt that the mistreatment of employees is harmful. However, there is limited evidence to suggest why these behaviors are so damaging to employees. Our results demonstrate that one possible reason for the harm is that employees perceive mistreatment as rejection of themselves. We also further investigated the important role of the workgroup in contributing to this harm. Specifically, we demonstrated that workgroup mistreatment results in increased levels of depression and damaged organization-based selfesteem, independent of supervisory mistreatment. This research has demonstrated the significant role of workgroup mistreatment and perceived rejection, and has contributed to greater theoretical and practical understanding of these issues.

\section{References}

Aquino, K., Galperin, B. L., \& Bennett, R. J. (2004). Social status and aggressiveness as moderators of the relationship between interactional justice and workplace deviance. Journal of Applied Social Psychology, 34, 126-138.

Ashforth, B. (1997). Petty tyranny in organizations: A preliminary examination of antecedents and consequences. Canadian Journal of Administrative Sciences, 14, 126-140.

Bandura, A. (1977). Social learning theory. Englewood Cliffs, NJ: Prentice Hall.

Baron, R. A., \& Neuman, J. H. (1996). Workplace violence and workplace aggression: Evidence of their relative frequency and causes. Aggressive Behavior, 22, 161-173.

Baron, R. M. \& Kenny, D. A. (1986). The moderatormediator variable distinction in social psychological research: Conceptual, strategic and statistical considerations. Journal of Personality and Social Psychology, 51, 1173-1182.

Bassman, E. (1992). Abuse in the workplace: Management remedies and bottom line impact. Westport, CT: Quorum Books.

Baumeister, R. F., Dewall, C. N., Ciarocco, N. J., \& Twenge, J. M. (2005). Social exclusion impairs selfregulation. Journal of Personality and Social Psychology, 88, 589-604.

Baumeister, R. F., \& Leary, M. R. (1995). The need to belong: Desire for interpersonal attachments as a fundamental human motivation. Psychological Bulletin, 117, 497-529.

Bennett, R. J., \& Robinson, S. L. (2000). Developing a measure of workplace deviance. Journal of Applied Psychology, 85, 349-360.

Bordia, P., Restubog, S. L. D., \& Tang, R. L. (in press). When employees strike back: Investigating mediating mechanisms between psychological contract breach and workplace deviance. Journal of Applied Psychology.

Bowling, N. A., \& Beehr, T. A. (2006). Workplace harassment from the victim's perspective: A theoretical model and meta-analysis. Journal of Applied Psychology, 91, 998-1012.

Britt, T. W., Dickson, J. M., Moore, D., Castro, C. A., \& Alder, A. B. (2007). Correlates and consequences of morale versus depression under stressful conditions. Journal of Occupational Health Psychology, 12, 34-37.

Brockner, J. (1988). Issues in organization and management series. Lexington, England: Lexington Books.

Bruk-Lee, V., \& Spector, P. E. (2006). The social stressescounterproductive work behaviors link: Are conflicts with supervisors and coworkers the same? Journal of Occupational Health Psychology, 11, 145-156.

Buhs, E. S. (2005). Peer rejection, negative peer treatment and school adjustment: Self-concept and classroom engagement as mediating processes. Journal of School Psychology, 43, 407-424.

Coie, J. D., Terry, R., Zakriski, A., \& Lochman, J. E. (1995). Early adolescent social influences on delinquent behavior. In J. McCord (Ed.), Coercion and punishment in long-term perspectives (pp. 229-244). New York: Cambridge University Press.

Craighead, W. E., Kimball, W. H., \& Rehak, P. J. (1979). Mood changes, physiological responses and self state- 
ments during social rejection imagery. Journal of Consulting and Clinical Psychology, 47, 385-396.

Crossley, C., Bennett, R. J., Jex, S., \& Burnfield, J. (2007). Development of a global measure of job embeddedness and integration into a traditional model of voluntary turnover. Journal of Applied Psychology, 92, 1031-1042.

Dodge, K. A., \& Coie, J. D. (1987). Social information processing factors in reactive and proactive aggression in children's peer groups. Journal of Personality and Social Psychology, 53, 1146-1158.

Donovan, M. A. Drasgow, F., \& Munson, L. J. (1998). The Perceptions of Fair Interpersonal Treatment scale: Development and validation of a measure of interpersonal treatment in the workplace. Journal of Applied Psychology, 83, 683-692.

Douglas, S. C., \& Martinko, M. J. (2001). Exploring the role of individual differences in the prediction of workplace aggression. Journal of Applied Psychology, 86, 547-559.

Duffy, M. K., Ganster, D. C., \& Pagon, M. (2002). Social undermining in the workplace. Academy of Management Journal, 45, 331-352.

Einaresen, S. (2000). Harassment and bullying at work: A review of the Scandinavian approach. Aggression and Violent Behavior: A Review Journal, 5, 379-401.

Faust, J., Baum, C. G., \& Forehand, R. (1985). An examination of the association between relationships and depression in early adolescence. Journal of Applied Developmental Psychology, 6, 291-297.

Frone, M. R. (2000). Interpersonal conflict at work and psychological outcomes: Testing a model among young workers. Journal of Occupational Health Psychology, 5, $246-255$.

Gardner, D. G., \& Pierce, J. L. (1998). Self-esteem and self-efficacy within the organizational context. Group \& Organization Management, 23, 48-70.

Gardner, W. L., \& Martinko, M. J. (1988). Impression management in organizations. Journal of Management, 14, 321-338.

Greenberg, J. (2006). Losing sleep over organizational injustice: Attenuating insomniac reactions to underpayment inequity with supervisory training in interactional justice. Journal of Applied Psychology, 91, 58-69.

Griffin, R. W., \& Lopez, Y. P. (2005). "Bad behavior" in organizations: A review and typology for the future. Journal of Management, 31, 998-1005.

Harvey, S., \& Keashly, L. (2003). Rumination: A psychological mechanism for transmitting and maintaining the effects of emotional abuse at work. Proceedings of the American Society for Business and the Behavioral Sciences, 10, 593-601.

Hirigoyen, M. G. (1998). Stalking the soul: Emotion abuse and the erosion of identity. New York: Helen Marx Books.

Hitlan, R. T., Cliffton, R. J., \& DeSoto, M. C. (2006). Perceived exclusion in the workplace: The moderating effects of gender on work-related attitudes and psychological health. North American Journal of Psychology, 8, 217-236.

Hitlan, R. T., Kelly, K., Schepman, S., Schneider, K. T., \& Zarate, M. A. (2006). Language exclusion and the consequences of perceived ostracism in the workplace. Group Dynamics: Theory, Research, and Practice, 10, $56-70$.

Hobman, E. V., Restubog, S. L. D., Bordia, P., \& Tang,
R. L. (in press). Abusive supervision in advising relationships: Investigating the role of social support. Applied Psychology: An International Review.

Hogg, M. A., \& Terry, D. J. (2000). Social identity and self-categorization processes in organizational contexts. Academy of Management Review, 25, 121-140.

Hollenbeck, J. R., \& Brief, A. P. (1987). The effects of individual differences and goal orientation on goal setting and performance. Organizational Behavior and $\mathrm{Hu}$ man Decision Processes, 40, 392-414.

Infante, D. A., \& Gorden, W. I. (1985). Superiors' argumentativeness and verbal aggressiveness as predictors of subordinates' satisfaction. Human Communication Research, 12, 117-125.

Inness, M., Barling, J., \& Turner, N. (2005). Understanding supervisor-targeted aggression: A within-person, between-jobs design. Journal of Applied Psychology, 90, 731-739.

Ironson, G. H., Smith, P. C., Brannick, M. T., Gibson, W. M., \& Paul, K. B. (1989). Construction of a job in general scale: A comparison of global, composite, and specific measures. Journal of Applied Psychology, 74, 193-200.

Jones, W. H. (1990). Loneliness and social exclusion. Journal of Social and Clinical Psychology, 9, 214-220.

Keashly, L., Trott, V., \& MacLean, L. (1994). Abusive behavior in the workplace. A preliminary investigation. Violence and Victims, 9, 341-357.

Kennedy, D. B., Homant, R. J., \& Homant, M. R. (2004). Perception of injustices as a predictor of support for workplace aggression. Journal of Business and Psychology, 18, 323-355.

Kessler, R. C., Akiskal, H., Ames, M., Bimbaum, H., Greenberg, R., Jin, R., et al. (2006). Prevalence and effects of mood disorders on work performance in a nationally representative sample of U.S. workers. American Journal of Psychiatry, 163, 1561-1568.

Lapierre, L. M., Spector, P. E., \& Leck, J. D. (2005). Sexual versus nonsexual workplace aggression and victims' overall job satisfaction: A meta-analysis. Journal of Occupational Health Psychology, 10, 155-169.

Leary, M. R. (2001). Interpersonal rejection. New York: Oxford University Press.

Leary, M. R., \& Baumeister, R. F. (2000). The nature and function of self-esteem: Sociometer theory. In M. Zanna (Ed.), Advances in experimental social psychology (Vol. 32, pp. 1-62). San Diego, CA: Academic Press.

Leary, M. R., \& Downs, D. L. (1995). Interpersonal functions of the self-esteem motive: The self-esteem system as a sociometer. In M. Kernis (Ed.), Efficacy, agency and self- esteem (pp. 123-144). New York: Plenum Press.

Leary, M. R., Kowalski, R. M., Smith, L., \& Phillips, S. (2003). Teasing, rejection, and violence: Case studies of the school shootings. Aggressive Behavior, 29, 202-214.

Leary, M. R., Springer, C., Negel, L., Ansell, E., \& Evans, K. (1998). The causes, phenomenology and consequences of hurt feelings. Journal of Personality and Social Psychology, 68, 518-530.

Lee, R. T., \& Brotheridge, C. M. (2006). When prey turns predatory: Workplace bullying as a predictor of counteraggression/bullying. European Journal of Work and Organizational Psychology, 16, 352-377.

Leymann, H. (1996). The content and development of mob- 
bing at work. European Journal of Work and Organizational Psychology, 5, 165-184.

MacDonald, G., \& Leary, M. R. (2005). Why does social exclusion hurt? The relationship between social and physical pain. Psychological Bulletin, 131, 202-223.

Markey, R., Hodgkinson, A., \& Kowalczyk, J. (2002). Gender, part-time employment and employee participation in Australian workplaces. Employee Relations, 24, 129-150.

Miceli, M. P., \& Near, J. P. (1984). The relationship among beliefs, organizational position and whistle-blowing status: A discriminant analysis. Academy of Management Journal, 27, 687-705.

Myers, S. A., \& Rocca, K. A. (2001). Perceived instructor argumentativeness and verbal aggressiveness in the college classroom: Effects on student perceptions of climate, apprehension and state motivation. Western Journal of Communication, 65, 113-137.

Neuman, J. J., \& Baron, P. E. (2005). Aggression in the workplace: A social-psychological perspective. In S. Fox \& P. E. Spector (Eds.), Counterproductive work behavior: Investigations of actors and targets (Vol. 7, pp. 13-40). Washington, DC: American Psychological Association

Pagal, M. D., Erdly, W. E., \& Becker, J. (1987). Social networks: We get by with (and in spite of) a little help from our friends. Journal of Personality and Social Psychology, 53, 793-804.

Pierce, J. L., Gardner, D. G., Cummings, L. L., \& Dunham, R. B. (1989). Organization-based self esteem: Construction, definition, measurement and validation. Academy of Management Journal, 32, 622-648.

Restubog, S. L. D., Bordia, P., \& Bordia, S. (in press). The interactive effects of procedural justice and equity sensitivity in predicting responses to psychological contract breach: An interactionist perspective. Journal of Business and Psychology.

Restubog, S. L. D., Bordia, P., \& Tang, R. L. (2007). Behavioral outcomes of psychological contract breach in a nonwestern culture: The moderating role of equity sensitivity. British Journal of Management, 18, 376-386.

Robinson, S. L., \& O'Leary-Kelly, A. M. (1998). Monkey see, monkey do: The influence of work groups on the antisocial behavior of employees. Academy of Management Journal, 41, 658-672.

Salancik, G. J., \& Pfeffer, J. (1978). A social information processing approach to job attitudes and task design. Administrative Science Quarterly, 23, 224-253.

Santor, D. A., \& Coyne, J. C. (1997). Shortening the CES-D to improve its ability to detect cases of depression. Psychological Assessment, 9, 233-243.

Schat, A. C. H., Frone, M. R., \& Kelloway, E. K. (2006).
Prevalence of workplace aggression in the U.S. workforce: Findings from a national study. In E. K. Kelloway, J. Barling, \& J. J. Hurrell (Eds.), Handbook of workplace violence (pp. 47-89). Thousand Oaks, CA: Sage.

Schneider, K. T., Hitlan, R. T., \& Radhakrishnan, P. (2000). An examination of the nature and correlates of ethnic harassment experiences in multiple contexts. Journal of Applied Psychology, 85, 3-12.

Sheppard, B. H., Lewicki, R. J., \& Minto, J. W. (1992). Organizational justice: The search for fairness in the workplace. New York: Lexington Books.

Shrout, P. E., \& Bolger, N. (2002). Mediation in experimental and nonexperimental studies: New procedures and recommendations. Psychological Methods, 7, 422-445.

Sobel, M. E., (1982). Asymptotic confidence intervals for indirect effects in structural equation models. In S. Leinhardt (Ed.), Sociological methodology (pp. 290-312) Washington, DC: Sociological Association.

Spector, P. E. (2006). Method variance in organizational research. Organizational Research Methods, 9, 221-232.

Spector, P. E., \& Jex, S. M. (1998). Development of four report measures of job stressors and strains: Interpersonal Conflict at Work Scale, Organizational Constraint Scale, Quantitative Workload Inventory, and Physical Symptom Inventory. Journal of Occupational Health Psychology, 3, 356-367.

Stecher, M. D., \& Rosse, J. G. (2005). The distributive side of interactional justice: The effects of interpersonal treatment on emotional arousal. Journal of Managerial Issues, 17, 229-246.

Tabachnick, B. G., \& Fidell, L. S. (2001). Using multivariate statistics (4th ed.). Needham Heights, MA: Allyn \& Bacon.

Tajfel, H., \& Turner, J. C. (1979). The social identity theory of inter-group behavior. In S. Worchel \& L. W. Austin (Eds.), Psychology of intergroup relations (pp. 94-109). Chicago: Nelson-Hall.

Tepper, B. J. (2000). Consequences of abusive supervision. Academy of Management Journal, 43, 178-190.

Twenge, J. M., Beaumeister, R. F., Tice, D. M., \& Stucke, T. S. (2001). If you can't join them, beat them: Effects of social exclusion on aggressive behavior. Journal of Personality and Social Psychology, 81, 1058-1069.

Weiss, H. M., \& Cropanzano, R. (1996). Affective events theory: A theoretical discussion of the structure, causes and consequences of affective experiences at work. Research in Organizational Behavior, 18, 1-74.

Williams, K. D., \& Sommer, K. L. (1997). Social ostracism by one's coworkers: Does rejection lead to loafing or compensation? Personality and Social Psychology Bulletin, 23, 693-706. 
Appendix

\section{Mistreatment Items}

1. Ridicules me

2. Hurts my feelings

3. Tells me my thoughts or feelings are stupid

4. Lets me know when they did not like me or something about me

5. Gives me the silent treatment

6. Talks bad about me behind my back

7. Breaks promises he/she makes

8. Spreads rumors about me

9. Reminds me of my past mistakes

10. Calls me names or degrades me

11. Doesn't give me credit for jobs requiring a lot of effort

12. Physically threatens me

13. Assigns me tasks far beyond my capabilities

14. Blames me to save himself/herself embarrassment

15. Denies me activity in the workplace

16. Expresses anger at me when he/she is mad for another reason

17. Makes negative comments about me to others

18. Is rude to me

19. Does NOT allow me to interact with others
20. Tells me I'm incompetent

21. Lies to me

22. Puts me down when I question work procedures

23. Undermines my effort to be successful on the job

24. Insults me

25. Yells at me or scolds me

26. Makes me feel incompetent

27. Delays work to make me look bad or slow me down

28. Talks down to me

29. Does NOT defend me when others speak poorly of me

30. Assigns me tasks far below my capabilities

31. Constantly critiques my work

32. Constantly critiques my private life

33. Physically abuses me

34. Forbids others at work to talk to me

35. Invades my privacy

Received October 19, 2007 Revision received May 8, 2008

Accepted June 2, 2008 